\title{
The ScanGel System Shows at least Equal Sensitivity for the Detection of Red Cell Antibodies in Comparison to the ID Micro Typing System
}

\author{
Volker Kretschmer Karin Schmidt Monika Bornmann Ralf Karger \\ Institut für Transfusionsmedizin und Hämostaseologie, Universitätsklinikum Marburg, Germany
}

\section{Key Words}

Red cell antibodies - Antibody screening - Gel test .

Crossmatch

\section{Summary}

Objective: The aim of this study was to compare 2 test systems for red cell antibody screening. Materials and Methods: 30 fresh and 92 stored frozen samples with known red cell antibodies (rbc-abs) and 356 consecutive blood samples sent in for routine serology were investigated in parallel using 2 different test systems: the ID Micro Typing System (test system A) and the ScanGel System (test system B). Results: Test system B demonstrated a significantly higher sensitivity (98.4 vs. 91.0\%, p $=0.019$ ) and equal specificity (99.7 vs. $100 \%$ ) compared to test system A. Conclusion: In this study, the ScanGel System was at least as good as the ID Micro Typing System in the detection of rbc-abs. It showed a significantly higher sensitivity that will have to be confirmed in prospective studies and across different batches of test cells.

\section{Introduction}

At the beginning of the last decade, the superiority of the gel centrifugation technique (ID Micro Typing System ${ }^{\circledR}$, DiaMed, Cressier sur Morat, Switzerland) compared to classical tube techniques for the detection of red cell antibodies (rbc-abs) was established [1-3]. Since then, it has become the standard

\section{Schlüsselwörter}

Erythrozytäre Antikörper · Antikörpersuchtest · Geltest . Kreuzprobe

\section{Zusammenfassung}

Ziel: Ziel war die Anfertigung einer vergleichende Studie zur Überprüfung der Gleichwertigkeit zweier Testsysteme zum Nachweis irregulärer erythrozytärer Antikörper. Material und Methoden: 356 Blutproben aus konsekutiven Routineanforderungen, 30 frische und 92 gelagerte Plasmen mit definierten erythrozytären Antikörpern wurden parallel im Antikörpersuchtest in 2 verschiedenen Testverfahren untersucht: dem ID Micro Typing System (Testsystem A) und dem ScanGel System (Testsystem B). Ergebnisse: Das Testsystem B zeigte eine signifikant höhere Sensitivität gegenüber Testverfahren A $(98,4$ vs. $91,0 \%, p=0,019)$ bei gleicher Spezifität $(99,7$ vs. $100 \%)$. Schlussfolgerung: In dieser Studie waren beide Testsysteme zumindest gleichwertig. Wir fanden sogar eine signifikant höhere Sensitivität des ScanGel-Systems, die aber erst in prospektiven Studien mit unterschiedlichen Chargen von Testzellen bestätigt werden muss.

\begin{tabular}{ll}
\hline KARGER & ( ) 2006 S. Karger GmbH, Freiburg \\
Fax +49 7614520714 & Accessible online at: \\
$\begin{array}{l}\text { E-mail Information@Karger.de } \\
\text { www.karger.com }\end{array}$ & www.karger.com/tmh \\
&
\end{tabular}

\section{KARGER}

E-mail Information
www.karger.com technique in many laboratories, even though modifications [4] and alternative methods [5], also not based on the tube technique, have become available. This method particularly lends itself to automation, because most of the test results can be clearly distinguished into negative or positive by automated reading. Thus, only the very few indeterminate results need to be interpreted visually or repeated [6]. This advantage has 
Table 1. Antigen pattern of antibody screening test cells (boldface: homozygous expression)
Antigen pattern

ID DiaCell D, C, E, c, e, C $C^{\mathrm{w}}, \mathrm{K}, \mathbf{k}, \mathbf{K p}^{\mathbf{b}}, \mathbf{J} \mathbf{s}^{\mathbf{b}}, \mathbf{F} \mathbf{y}^{\mathbf{a}}, \mathbf{F y}^{\mathbf{b}}, \mathbf{J k}^{\mathbf{a}}, \mathbf{J k}^{\mathbf{b}}, \mathrm{Le}^{\mathrm{a}}, \mathrm{Le}^{\mathrm{b}}, \mathrm{P}_{1}, \mathbf{M}, \mathbf{N}, \mathbf{S}, \mathbf{s}, \mathrm{Lu}^{\mathrm{a}}, \mathbf{L u}^{\mathbf{b}}, \mathrm{Xg}^{\mathrm{a}}$

ScanCell D, C, E, c, e, C $C^{\mathrm{w}}, \mathrm{K}, \mathbf{k}, \mathbf{K}^{\mathbf{b}}, \mathbf{F} \mathbf{y}^{\mathbf{a}}, \mathbf{F y}^{\mathbf{b}}, \mathbf{J k}^{\mathbf{a}}, \mathbf{J k}^{\mathbf{b}}, \mathrm{Le}^{\mathrm{a}}, \mathrm{Le}^{\mathrm{b}}, \mathrm{P}_{1}, \mathbf{M}, \mathrm{N}, \mathbf{S}, \mathbf{s}, \mathrm{Lu}^{\mathrm{a}}, \mathbf{L u}^{\mathbf{b}}\left(\mathrm{Js}^{\mathrm{b}}\right.$ and Xg $\mathrm{Xg}^{\mathrm{a}}$ were not listed in the panel sheet, considering their frequency they were supposed to be present) led to the development of several instruments aimed at automated blood group serology. Solutions for laboratories with smaller sample throughputs or for the screening of patient samples in particular have been introduced. Meanwhile, a further modification of the gel technique (ScanGel System ${ }^{\circledR}$, Bio-Rad Laboratories, Marnes-la-Coquette, France, distribution in Germany MTC-med. Produkte GmbH, Bensheim, Germany) has become available. It was the aim of this study to examine whether the sensitivity and specificity obtained with the ScanGel System are comparable to the ID Micro Typing System which was the standard technique in our laboratory for many years.

\section{Materials and Methods}

356 fresh, consecutive blood samples (EDTA) from our routine blood group laboratory were screened in parallel. In addition, 30 fresh EDTA plasma samples from patients with 38 irregular rbc-abs were investigated. 6 samples contained antibody mixtures: anti-C,-D,-E (2), anti-C,-D (3), anti-Fya ${ }^{a}-\mathrm{E}(1)$. The rbc-abs were either discovered during the study period or had been found in the past mainly with the standard method (see below), and were now being re-investigated upon readmission of those patients. We also included 92 patient plasma samples (114 rbc-abs) which had been stored below $-25^{\circ} \mathrm{C}$. These rbc-abs had also been found mainly by using the standard method. Only few antibodies derived from our reference laboratory and were primarily detected by the BioVue test (Ortho BioVue $^{\circledR}$, Ortho Diagnostics, Neckargemünd, Germany). 16 of these samples contained antibody mixtures: anti-C,-D,-E (1), anti-C,-D (3), anti$\mathrm{C}^{\mathrm{w}}$,-E (1), anti-C,-D,-Fy ${ }^{\mathrm{a}}$ (3), anti-C,-D,-k (2), anti-C,-D,-Jk ${ }^{\mathrm{a}}$ (1), anti-E, $\mathrm{Fy}^{\mathrm{a}}(2)$, anti-K,-Fy ${ }^{\mathrm{a}}(2)$, anti-K,-Jk ${ }^{\mathrm{a}}$ (1). Additional antibodies of antibody mixtures which could not be detected because the test cells were lacking the corresponding antigens were not listed. Since thawed plasmas have $\mathrm{pH}$ values between 8 and 9, we carefully restored them to $\mathrm{pH} 7.4$ by adding $0.1 \mathrm{~N} \mathrm{HCl}$. Table 1 gives an overview over the antigen pattern of the antibody screening test cells used.

The standard method (test system A) was the ID Micro Typing System using polyspecific LISS/AHG cards (lot no. 50531.29.37), monospecific anti-IgG cards (lot no. 50540.39.04/ 50540.45.05) and ID-DiaCell I-II-III test cells (DiaMed, lot no. 45184.27.1). We compared our standard technique with the ScanGel System (test system B) using polyspecific antiIgG, anti-C3d cards (lot no. 50280.02), monospecific anti-IgG cards (lot no. 50713.01) and ScanCell I-II-III test cells (lot no. T21.05). The test cell panels of both systems each originated from 3 different donors and had almost identical expiry dates (test system A: October 3, 2005, test system B: October 2, 2005). Both test cell panels exhibited all the antigens necessary to detect the rbc-abs specificities present in our collection of samples. The test procedure was performed according to the respective manufacturers' package insert by an experienced technician. Reading was carried out visually by 2 experienced technicians. Agglutination was scored from 0-4. For the determination of rbc-abs specificities, additional tests were performed using the ID and/or BioVue test systems with different incubations (either at $37^{\circ} \mathrm{C}$ or bithermic with $15 \mathrm{~min}$ at $37^{\circ} \mathrm{C}$ followed by $15 \mathrm{~min}$ at room temperature) and/or the CaptureR test system (Immucor Gamma, Rödermark, Germany), depending on the nature of the suspected antibody. Sensitivity and specificity of test systems A and B were calculated using the entire panel of applied techniques, except the system under evaluation, as gold standard, and were tested for statistically significant differences with Fisher's exact test. Positive reactions in the antibody screening tests were defined as nonspecific, when the identification tests in the various test methods mentioned before remained negative or did not show reactions which corresponded to any specific antigen pattern. Test results of this type are usually not taken into account for blood transfusion.

\section{Results}

\section{Routine Samples}

Only 2 out of 356 patient samples showed discrepant results between the 2 methods using AHG cards. Both samples reacted only in test system B (sample 1: 1-2+ with all 3 test cells, sample 2: $1+$ with 1 test cell) and were reproducibly positive. Sample 1 was identified as anti-M. Sample B was non-reactive in the following antibody identification tests with ScanGel und Capture R, thus reactivity was classified as 'nonspecific'.

101 patient samples were tested with anti-IgG cards and showed negative results with both systems. In this follow-up, sample 2 was negative, sample 1 was not included.

\section{Fresh Samples with Irregular Red Cell Antibodies}

Only 5 out of 30 samples reacted in both systems using AHG cards, with a maximum reaction strength of $4+$ with at least 1 of the 3 test cells. Most samples (25 out of 30 ) did not react with maximum strength in both tests, thus allowing the analytic sensitivity of the systems to be compared without the need to perform titration studies. 3 samples reacted 1 grade stronger in test system B, leading to a weakly reacting anti-E only being detected by this test system (table 2). Only those antibody specificities are listed where the positive reacting test cells had the corresponding antigen. The specific antibodies of antibody mixtures causing positive reactions remained unclear in most of these plasma samples, because the test cells exposed both or all antigens against which the different antibodies were directed. Using IgG cards, all tested antibodies were detected in both systems. Except 1 anti-M, all antibodies were IgG rbc-abs. In 2 cases, the reaction strength in test system $\mathrm{A}$ was 1 grade stronger. In another case, reaction test system B was 1 grade stronger. 
Table 2. Number of positive reacting plasmas and rbc-abs in 30 fresh patient plasmas investigated with polyspecific anti-AHG cards

\begin{tabular}{lllll}
\hline $\begin{array}{l}\text { Antibodies in tested } \\
\text { plasma samples }\end{array}$ & $\begin{array}{l}\text { Plasma samples, } \\
\mathrm{n}\end{array}$ & $\begin{array}{l}\text { In both test systems } \\
\text { positive plasma } \\
\text { samples (detected } \\
\text { antibodies), } \mathrm{n}\end{array}$ & $\begin{array}{l}\text { Antibodies only } \\
\text { detected in test } \\
\text { system A, n }\end{array}$ & $\begin{array}{l}\text { Antibodies only } \\
\text { detected in test } \\
\text { system B, } \mathrm{n}\end{array}$ \\
\hline Anti-E & 6 & 5 & - & 1 \\
Anti-D & 7 & 7 & - & - \\
Anti-C, anti-D & 3 & $3^{*}$ & - & - \\
Anti-C, anti-D, anti-E & 2 & $2^{*}$ & - & - \\
Anti-C & 2 & 2 & - & - \\
Anti-E, anti-Fy & 1 & 1 (anti-E + anti-Fy $\left.{ }^{\mathrm{a}}\right)$ & - & - \\
Anti-Fy & 1 & 1 & - & - \\
Anti-K & 4 & 4 & - & - \\
Anti-Jk & 2 & 2 & - & - \\
Anti-M $^{\mathrm{a}}$ & 2 & 1 & - & 1 \\
\hline
\end{tabular}

*Due to the antigen distribution, it cannot be distinguished which antibodies of the antibody mixture were responsible for the positivity of the antibody screening tests.

\section{Frozen Samples with Irregular Antibodies}

Again, in both systems using polyspecific AHG cards, only 16 out of 92 samples $(17.4 \%)$ showed reactions of maximum strength (4+), prohibiting a comparison of the analytic sensitivity in these samples. 2 plasmas with anti- $\mathrm{P}_{1}$ and anti-M were not reactive in either of the systems. 15 samples (16.3\%) reacted stronger in test system B (13 samples $1+$ stronger, 1 sample $2+$ stronger, 2 samples $3+$ stronger). This means that 9 plasmas (10 abs) with rbc-abs were detected exclusively by the test system B: 2 anti-Le ${ }^{\mathrm{a}}, 2$ anti-M, 1 anti-K, 1 anti- $\mathrm{P}_{1}, 1$ anti$\mathrm{C}^{\mathrm{w}}, 1$ anti- $\mathrm{C}^{\mathrm{w}}+-\mathrm{E}$ and 1 anti-C. In addition, in 1 plasma, a second antibody (anti-K) did only present positive in test system B. In contrast, test system A reacted 1+ stronger with only 5 samples but did not detect any additional antibody (table 3).

The results obtained with anti-IgG cards were almost identical: only 16 out of 92 samples $(17.4 \%)$ showed reactions of maximum strength in both test systems, 15 samples (16.3\%) reacted stronger in test system B (13 samples 1+, 2 samples 3+ stronger). In contrast, test system A only reacted $1+$ stronger in 4 samples. 1 anti- $\mathrm{P}_{1}$ was not detectable in both test systems. The anti-M that was not reactive with polyspecific AHG cards, weakly reactive with test system B (IgG card) (1+) and not reactive in test system A. Therefore, the number of plasma samples with rbc-abs which were only detectable in test system $B$ increased to 10: 2 anti-Le ${ }^{\mathrm{a}}, 3$ anti-M, 1 anti-K, 1 anti- $\mathrm{P}_{1}$, 1 anti-C ${ }^{\mathrm{w}}, 1$ anti- $\mathrm{C}^{\mathrm{w}}+-\mathrm{E}, 1$ anti-C. Again, in 1 plasma, an anti$\mathrm{K}$ was found in addition to anti-Fy ${ }^{\mathrm{a}}$ with test system $\mathrm{B}$.

\section{Sensitivity and Specificity}

Whereas neither with polyspecific AHG nor with monospecific anti-IgG cards the specificities of test systems A and B were significantly different, test system $B$ demonstrated a significantly higher sensitivity with both cards $(\mathrm{p}=0.019$ and
0.005 , respectively; table 4$)$. The higher sensitivity was primarily due to the increased detection of naturally occurring rbcabs in 5 out of 24 samples (20.8\%): 2 anti-M, 2 anti-Le ${ }^{\mathrm{a}}, 1$ anti$\mathrm{P}_{1}$. However, 5 clinically relevant rbc-abs in 107 samples (4.7\%) were found with test system B but not system A: 2 cases of anti-K, and 1 case each of anti-E, anti- $\mathrm{C}^{\mathrm{w}}$ and anti-C, respectively.

\section{Discussion and Conclusion}

It was the aim of this study to establish to what extent the ScanGel System is comparable with the established ID Micro Typing System in terms of the detection of rbc-abs. There have been previous reports from laboratories of cases of clinically relevant antibodies of low titer that had not been reliably detected by the ScanGel System. For this reason, the manufacturer changed the suspension medium for the test cells. This study was undertaken with test cells suspended in the new suspension medium. We screened a representative number of routine patient samples as well as fresh and stored plasmas with irregular rbc-abs in order to determine the comparability of both test systems. To prevent false results caused by $\mathrm{pH}$ changes in frozen plasmas, the $\mathrm{pH}$ of the thawed samples was adjusted to the physiological value immediately prior to testing. The screened samples represent the typical spectrum of irregular rbc-abs of the Rh, Kell, Kidd and Duffy systems. The majority of fresh and frozen antibodies were weakly reactive (low titer) antibodies, which is an advantage for comparative testing, because differences in reaction strength can be detected without titration experiments.

The results of this investigation suggest a significantly higher sensitivity and equal specificity of the ScanGel System compared to the ID Micro Typing System. However, disproportionately more naturally occurring rbc-abs of questionable clinical relevance were detected with the ScanGel System. 
Table 3. Number of positive reacting plasmas and rbc-abs RBC-abs in 92 thawed patient plasma samples investigated with polyspecific antiAHG cards (17 plasmas with antibody mixtures)

\begin{tabular}{|c|c|c|c|c|}
\hline $\begin{array}{l}\text { Antibodies in tested } \\
\text { plasma samples }\end{array}$ & $\begin{array}{l}\text { Plasma samples, } \\
\mathrm{n}\end{array}$ & $\begin{array}{l}\text { In both test systems positive } \\
\text { plasma samples } \\
\text { (detected antibodies) }\end{array}$ & $\begin{array}{l}\text { Antibodies only } \\
\text { detected in test } \\
\text { system A }\end{array}$ & $\begin{array}{l}\text { Antibodies only } \\
\text { detected in test } \\
\text { system B }\end{array}$ \\
\hline Anti-C & 5 & 4 & - & 1 \\
\hline Anti-D & 1 & 1 & - & - \\
\hline Anti-C, anti-D & 3 & $3 *$ & - & - \\
\hline Anti-C, anti-D, anti-E & 1 & $1 *$ & - & - \\
\hline Anti-E & 7 & 7 & - & - \\
\hline Anti-c & 2 & 2 & - & - \\
\hline Anti-C $C^{w}$ & 4 & 3 & - & 1 \\
\hline Anti-c, anti-E & 2 & $2 *$ & - & - \\
\hline Anti- $\mathrm{C}^{\mathrm{w}}$, anti-E & 1 & - & - & $1\left(\right.$ anti- $\mathrm{C}^{\mathrm{w}}+$ anti-E) \\
\hline Anti-C, anti-D, anti-Fy ${ }^{\mathrm{a}}$ & 3 & $3 *$ & - & - \\
\hline Anti-E, anti-Fy ${ }^{\mathrm{a}}$ & 2 & $2\left(\right.$ anti-E + anti-Fy ${ }^{\mathrm{a}}$, each $)$ & - & - \\
\hline Anti-C, anti-D, anti-k & 2 & $2($ anti-C, D + anti-k, each) & - & - \\
\hline Anti-C, anti-D, anti-Jk ${ }^{\mathrm{a}}$ & 1 & $1 *$ & - & - \\
\hline Anti-K & 17 & 16 & - & 1 \\
\hline Anti-K, anti-Fy ${ }^{\mathrm{a}}$ & 1 & $1\left(\right.$ anti-K + anti-Fy $\left.{ }^{\mathrm{a}}\right)$ & - & - \\
\hline Anti-K, anti-Fy ${ }^{\mathrm{a}}$ & 1 & $1\left(\right.$ only anti-Fy $\left.{ }^{a}\right)$ & - & $1($ anti-K) \\
\hline Anti-k & 1 & 1 & -- & \\
\hline Anti-Jk ${ }^{\mathrm{a}}$ & 3 & 3 & - & - \\
\hline Anti-Jk ${ }^{\mathrm{b}}$ & 1 & 1 & - & - \\
\hline Anti-Fy & 9 & 9 & - & - \\
\hline Anti-Lu ${ }^{\mathrm{a}}$ & 2 & 2 & - & - \\
\hline Anti-M & 9 & 3 & - & 2 \\
\hline Anti-N & 2 & 2 & - & - \\
\hline Anti-S & 4 & 4 & - & - \\
\hline Anti-P 1 & 2 & 1 & - & 1 \\
\hline Anti-Le & 5 & 3 & - & 2 \\
\hline
\end{tabular}

*Due to the antigen distribution it cannot be distinguished which antibodies of the antibody mixture were responsible for the positivity of the antibody screening tests.
These rbc-abs are usually IgM antibodies which only in rare cases cause transfusion reactions if not taken into account [7]. However, those rbc-abs were also detected with monospecific anti-IgG cards and are thus supposed to be of the $\operatorname{IgG}$ type. This increases the likelihood that they might be of clinical relevance upon transfusion. However, rbc-abs with known clinical significance, such as anti-K and $\mathrm{Rh}$ antibodies, were also better detected by the ScanGel System.

One advantage of the ScanGel System might be the greater transparency of the cards rendering them easier to interpret, also by automatic readers, particularly if the cards are to be read only from one side. On the other hand, the agglutinates seemed to be a little smaller in the ScanGel System, which is perhaps due to the lower concentration of the test cell suspension $(0.6 \%$ compared to $0.8 \%)$. Whether this fact has an influence on automatic reading, needs to be further investigated. It remains to be seen whether similar results are obtained with different lots of cards and test cells, because in this study only 1 lot of cards (except for the anti-IgG cards) and test cells were used. In a subsequent study including antibody titration and using another test cell batch, we were also able to demonstrate a slight superiority of the ScanGel System (unpublished data). However, further investigations are needed to prove the consistent good quality of the ScanGel System and in par-
Table 4. Sensitivities and specificities of both test systems

\begin{tabular}{lrrrr}
\hline & \multicolumn{3}{l}{ Test system } \\
\cline { 2 - 5 } & \multicolumn{2}{l}{ Polyspecific AHG card } & \multicolumn{2}{l}{ Monospecific anti-IgG card } \\
\cline { 2 - 5 } & A & B & A & B \\
\hline Sensitivity & 91.0 & $98.4^{*}$ & 91.0 & $99.2^{* *}$ \\
Specificity & 100.0 & 99.7 & 100.0 & 100.0
\end{tabular}

* $\mathrm{p}=0.019$.

$* * \mathrm{p}=0.005$ (Fisher's exact test).

ticular the test cells. At present, the ScanGel system is considered to be at least as good as the ID Micro Typing System.

The ScanGel System has now been implemented in our routine immunohematology for several months and in automated testing for several weeks. The experience confirms the results of the study.

\section{Acknowledgement}

This study was sponsored by BIO-RAD SA France and MTC-med. Produkte GmbH Bensheim, Germany. 


\section{References}

1 Hitzler W, Johannson C, Schöming-Brekner J, Mathias D: Comparative study of antibody identification in the gel centrifugation test (ID Micro Typing System), solid phase system (Solidscreen, Capture R, Ready ID) and Tube Test. Ärztl. Lab 1991;37:137-146.

- Kretschmer V, Heuckeroth A, Schulzki T, Dietrich G: Superiority of gel centrifugation in antibody screening and identification. Infusionstherapie 1992;19:226-230.

3 Reis KJ, Chachowski R, Cupido A, Davies D, Jakway J, Setcavage TM: Column agglutination technology: the antiglobulintest. Transfusion 1993; 33:639-643.

4 Eichler H, Klinge U, Kretschmer V: ID- und BioVue-System - Vergleich zweier Systeme zur Erfassung erythrozytärer Antikörper. Beitr Infusionsther Transfusionsmed. Basel, Karger, 1994, vol 32, pp 149-152.

5 Zeiler T, Thiele S, Kretschmer V: Festphasentechnik versus Gelzentrifugation zum Nachweis erythrozytärer Antikörper - eine prospektive Studie zum Vergleich zweier Antikörpersuchtests; in Sibrowski W, Stangel W, Blauhut B (eds): Transfusionsmedizin 1995/96. Beitr Infusionsther Transfusionsmed. Basel, Karger, 1996, vol 33, pp 17-21

6 Kretschmer V, Sonneborn H H: Blutgruppenantigene und -antikörper; in Lothar Thomas (eds) Labor und Diagnose: Indikation und Bewertung von Laborbefunden für die medizinische Diagnostik, ed 6. Frankfurt/Main, TH-Books, 2005, pp 1226-1290.

7 Issitt PD, Anstee DJ: Applied Blood Group Serology, ed 4. Durham, Montgomery Scientific Publications, 1998. 